\title{
Evaluation of structural irregularities based on architectural design considerations in Turkey
}

Evaluation of structural irregularities

303

\author{
Tugba İnan and Koray Korkmaz \\ Department of Architecture, Izmir Institute of Technology, Izmir, Turkey
}

\begin{abstract}
Purpose - The purpose of this research is to show significant points which can be used in the architectural design process by investigating the basic principles of earthquake resistant design (ERD) in a deductive format and to contribute to the architectural perception in ERD.

Design/methodology/approach - First, the structural irregularity types are examined depending on the rules defined in the Turkish Earthquake Code, 2007 (TEC). Then, architectural design failures related to earthquake resistance of buildings under earthquake loading are visualized and solution suggestions in literature are described in detail by supported drawings.

Findings - The problems causing structural irregularities are investigated deeply with given solutions in literature. It is obtained that the significant factors affecting the earthquake performance of structures are: architectural form, structural configuration, slenderness ratio, the location and rate of floor openings, projection rates and symmetry, rigidity and strength differences between floors, short columns, pounding effect.

Social implications - The practical design decision rules can contribute to the phenomena of earthquake resistant architectural design and can encourage adoption of these rules in building industry.

Originality/value - This study aims to gain an understanding of the problems in projects in terms of structural irregularities, and then manage to solve the problems using problem-oriented approaches. The suggested solutions can be adopted and applied to future projects for designing earthquake resistant buildings.
\end{abstract}

Keywords Earthquakes, Structural irregularities, Earthquake resistant architectural design, Turkish Earthquake Code, Turkey

Paper type General review

\section{Introduction}

Turkey, with more than 90 per cent of its land being in highly seismic regions, is an earthquake prone country and has been struck by many devastating earthquakes throughout history. During the last century, 21 earthquakes took place with magnitudes $>7$. More than 80,000 people have died and about 500,000 building collapsed or were heavily damaged (Çağatay, 2005).

All buildings are exposed to devastating earthquake loads during earthquakes. However, while some buildings suffer damage or complete collapse under these loads, others can remain standing with slight damage. The earthquake behaviour of buildings depends on many factors such as architectural design, configuration of structural elements in plan and vertical direction, earthquake zone, geographical location (closeness to the fault line), soil type, quality of materials, proper construction, etc. As, earthquake forces affect the whole building, earthquake resistance of a building should be a major issue in the responsibility of various professionals and people related to the buildings construction such as architects, civil engineers, building constructors, city planners, etc. (Zacek, 2002). Each discipline has different significant

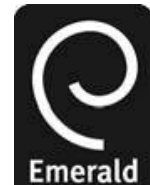

Structural Survey Vol. 29 No. 4, 2011 pp. $303-319$

C Emerald Group Publishing Limited 0263-080X 
$\mathrm{SS}$

29,4

304 responsibilities about their own roles in earthquake resistant design (ERD) (Dowrick, 1987; Bachman, 2003).

Turkey is an earthquake country and it is expected that it can deal with earthquakes in the future, by managing future collapses of structures (Mertol and Mertol, 2002). The structural problems caused by an earthquake are generally seen as an engineering problem even though they can be eliminated through the design phase. It is usually studied by structural engineers and their language is too complicated for architects to understand (Özmen and Ünay, 2007).

Architectural design decisions have a significant effect on earthquake behaviour of structures and influences the seismic performance of the building due to the particularly building and structural system configuration issues (Tuna, 2000; Gönençen, 2000; Zacek, 2002). Earthquake resistant architectural principles are not provisions that could be inserted by the structural engineer after the completion of architectural design (Erman, 2002). Failures in the architectural design phase cannot be regulated by calculations or a detailed structural design done later by the structural engineer (Ersoy, 1999). They should be applied to the project during the architectural design phase. Architectural design process plays an active role in the earthquake behaviour of structures (Arbabian, 2000).

The study presents a broad outline on structural irregularities based on Turkish Earthquake Code (TEC) in order to emphasize the architectural design faults and develop a substantial guide for architects and students of architecture for designing earthquake resistant buildings. It describes basic problems in plan and structural system configuration, which are frequently encountered at the initial phase of design.

\section{Structural irregularities}

Irregular buildings are defined in the TEC as buildings whose design and construction should be avoided because of their unfavourable seismic behaviour (TEC, 2007). Structural irregularities begin in the initial part of the architectural design phase. There are many factors causing structural irregularity and affects badly earthquake performance of buildings. These are irregular design in plan and vertical direction, discontinuity in mass and rigidity distribution, configuration of structural elements on nonparallel axis, height differences between floors, short columns, pounding effects, etc. (Tezcan, 1998). Structural irregularities are divided into two basic groups as irregularities in plan and vertical direction (TEC, 2007). Irregularities in plan consist of four different types of structural irregularity. These are torsional irregularity denoted as A1, floor discontinuities denoted as A2, projections in plan denoted as A3, nonparallel structural member axes denoted as A4. Irregularities in vertical direction comprise of three types of structural irregularity. These are weak storey denoted as B1, soft storey denoted as B2, discontinuity of structural elements denoted as B3. Apart from the categorized structural irregularities, short column effect, weak columnstrong beam irregularity and seismic pounding effects are investigated comprehensively under different sub-headings (Table I).

\section{Structural irregularities in plan}

Irregularities in plan consist of four different types of structural irregularity. These are torsional irregularity, floor discontinuities, projections in plan, and nonparallel structural member axes. In this section, irregularities in plan are evaluated in detail with their solutions. 


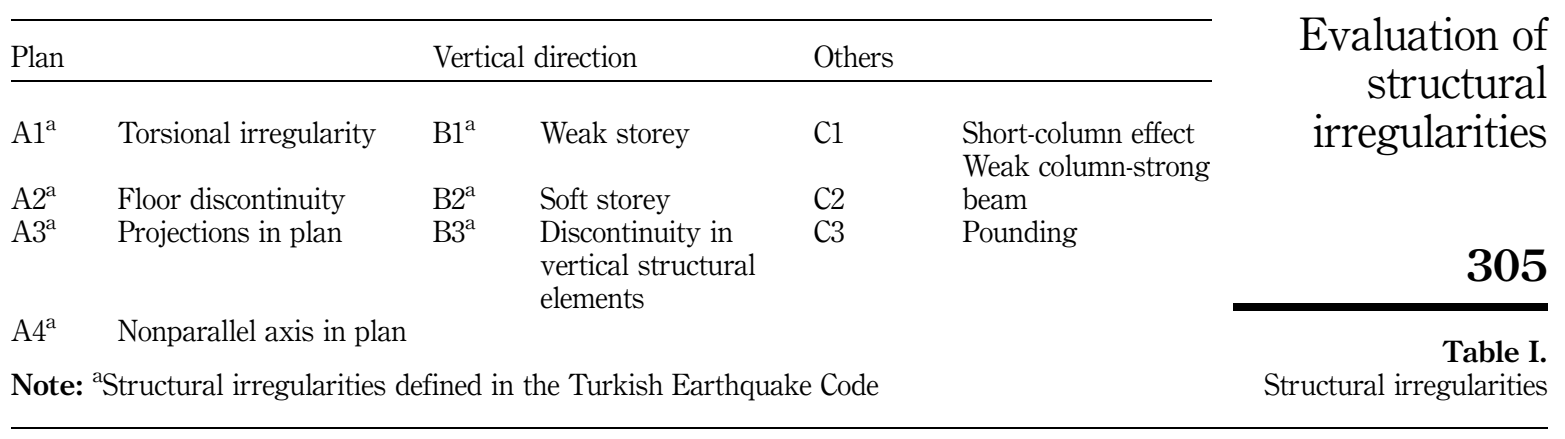

\subsection{Torsional irregularity (A1) and solution suggestions}

Various seismic codes define torsional irregularity as a significant irregularity, because of its devastating effects on buildings (Gülay and Çalım, 2003). Torsional irregularity is the case where torsional irregularity factor $\left(\eta_{b i}\right)$ defined for any of the two orthogonal earthquake directions as the ratio of the maximum storey drift at any storey to the average storey drift at the same storey in the same direction, is $>1.2$ (Figure 1). The \pm 5 per cent additional eccentricity is considered in the displacement computations on both earthquake directions if torsional irregularity occurs in that structure (TEC, 2007).

$$
\eta_{b i}=\frac{\Delta i_{\max }}{\Delta i_{\text {avg }}}>1.2
$$

Earthquake loads affect on gravity centre of the structure $(G)$. However, the rigidity centre of the structure $(R)$ responds to these loads (Figure 2). If the eccentricity between these two centres is great, a torsional moment will occur around the centre of rigidity

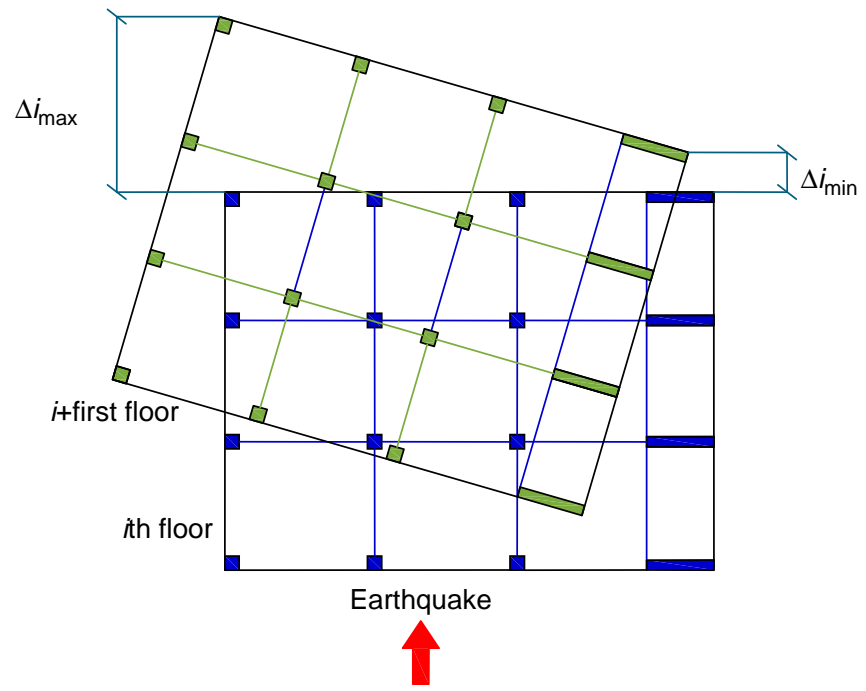

Figure 1. Torsional irregularity 
SS

29,4

\section{6}

Figure 2.

Working mechanism of gravity and rigidity centre

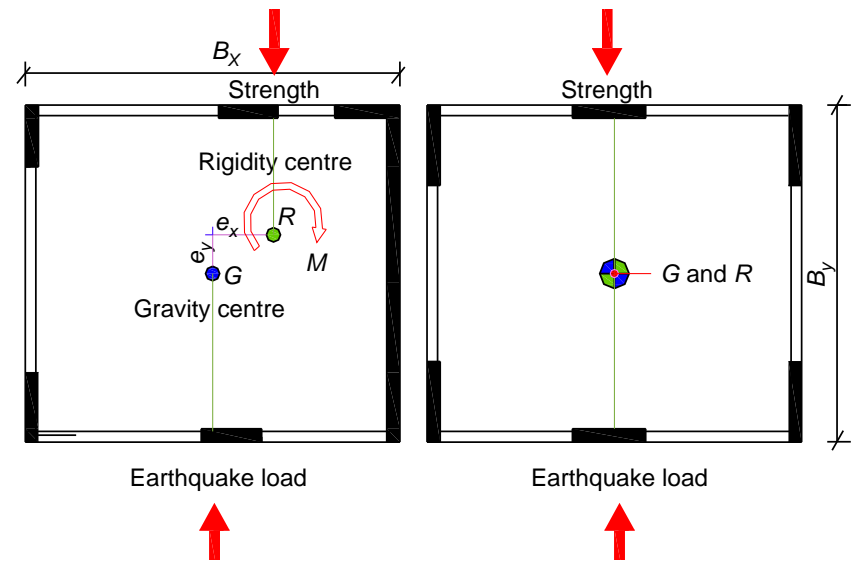

and the structure begins to rotate around the rigidity axis (Arnold and Reitherman, 2002). Torsional irregularity exists on a structure due to the plan geometry or the structural member's rigidity distribution (Özmen, 2004; Döndüren et al., 2007; Bayülke, 2001).

Building design is the geometrical arrangement of all the architecture, structure and contents. It should include both appropriate form and the structural arrangement. It is easier to understand the overall behaviour of a simple structure under earthquake loading rather than the complex one (Ambrose and Vergun, 1985). The most appropriate form in terms of earthquake loads is circle and square due to their symmetric and simple plan geometry (Naeim, 2001). Because, it reacts to the same inertia forces under earthquake loads coming from in every direction. Structures which have asymmetric and complex plan geometry such as L, H, T, U, Y, +, have little energy absorbing capacity due to the torsional effects and stress concentrations at notch points (Atımtay, 2000; Charleson, 2008). On the other hand, simple forms usually provide simple details in the design stage than complex ones (Zacek, 2002).

The complex shapes cause two major problem: torsion and variations of rigidity (Naeim, 2001). In accordance with the coming together of the different blocks in the structure, the building becomes susceptible against earthquake loads especially on notch points at reentrant corners due to the torsion and stress concentration. Both of the wings display different movements pushing and pulling each other at notch points.

Apart from the plan geometry, rigidity distribution in plan cause torsional irregularity. It creates abrupt increase in the torsional irregularity coefficients despite the regular plan geometry (Atımtay, 2000; Özmen, 2004; Charleson 2008; Inan, 2010). For instance, if shear walls or rigid core are located on one side of the building, flexible and rigid parts occur in the structure. Torsional irregularity occurs due to the great distance between rigidity and gravity centre of the structure (Karaesmen, 2002).

It is quite difficult to change the centre of gravity of a structure. However, the centre of rigidity can be changed by modifying the location of the structural elements or their cross-sections. Torsion occurs around a vertical axis that can cause collapses in the farthest edge or corner columns due to the distance between rigidity and gravity centre (Aka et al., 2001).

Variations in perimeter strength and stiffness cause torsion on buildings (Naeim, 2001; Dimova and Alashki, 2003). Buildings are usually orientated towards to the scene 
such as beachfront apartments, which are designed with open frontage facing to the beach. This orientation prevents the distribution of the strength and rigidity equally at the perimeter of the buildings. It causes unbalanced perimeter resistance and major torsional moments. Bank halls, shops, and department stores can be exemplified for these types of buildings in which large windows are necessary for exhibition.

Solution suggestions for preventing the torsional irregularity can be defined as follows:

- separating complex forms into simple and compact forms by using seismic separation joints (Figure 3);

- minimizing the distance between the gravity and rigidity centre;

- providing symmetry both in the building form and rigidity distribution (Ambrose and Vergun, 1985);

- placing infilled walls as symmetrical as possible due to the effects on changing the rigidity centre except from the columns and shear walls (Ersoy, 1999); and

- strengthening of flexible sides.

Open facades or the distance between rigidity and gravity centre cause flexible and rigid sides in a building. To prevent this condition, rigid cores and shear walls can be used (Zacek, 2002):

- Strengthening of acute angle reentrant corners - the buildings which have acute angle corners such as the plan geometry of $\mathrm{L}$ and $\mathrm{T}$ types are strengthened at notch points by vertical structural members (Zacek, 2002).

- Softening of acute angle reentrant corners - the wings of a building which is connected with an angle of $90^{\circ}$ or lower than the $90^{\circ}$ should be combined with circular lines (Figure 4). Thus, the wings of the building move as a whole during earthquake (Zacek, 2002). Torsional irregularity can be prevented with this method (Table II).

\subsection{Floor discontinuities (A2) and solution suggestions}

The location of the floor discontinuity, its rate and its interaction with structural elements affect the earthquake behaviour of buildings. Earthquake loads are transmitted to the vertical structural elements through slabs. It is assumed that they act on every floor level of the structure. Therefore, there is a considerable accumulated seismic energy on floors. Floor openings make it difficult to transfer directly the earthquake forces to the vertical structural elements and cause stress concentration
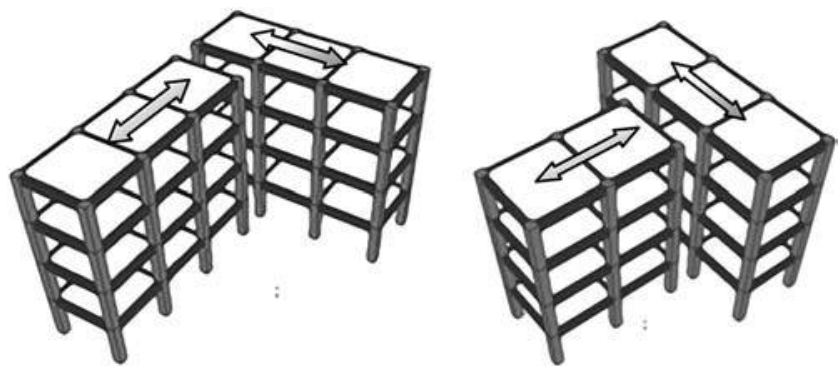

Figure 3. Seismic joints 
SS

29,4

308

Figure 4.

Softening reentrant corners

\section{Table II.}

Torsional coefficients
(Celep and Kumbasar, 2004). Conditions causing floor discontinuity is described in the TEC (Figure 5), in any floor:

(1) The case where the total area of the openings including those of stairs and elevator shafts exceeds one-third of the gross floor area.

(2) The cases where local floor openings make it difficult the safe transfer of seismic loads to vertical structural elements.

(3) The cases of abrupt reductions in the in-plane stiffness and strength of floors.

$$
A_{b} / A>1 / 3
$$

where $A_{b}$ is the total area of openings, $A$ is gross floor area.
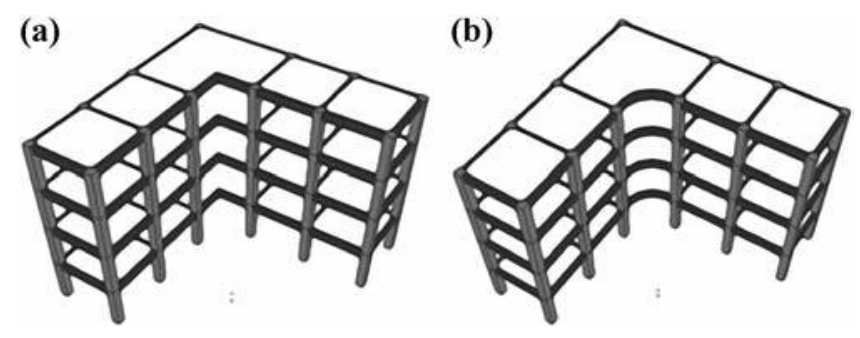

Notes: (a) before softening; (b) after softening

\begin{tabular}{lcc}
\hline & $\eta_{\mathrm{b}}(\mathrm{a})$ & $\eta_{\mathrm{b}}(\mathrm{b})$ \\
\hline 3 & & \\
2 & 1.21 & 1.19 \\
1 & 1.19 & 1.18 \\
Ground & 1.18 & 1.17 \\
& 1.17 & 1.16 \\
\hline
\end{tabular}

(a)

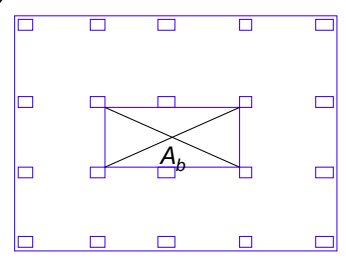

(b)

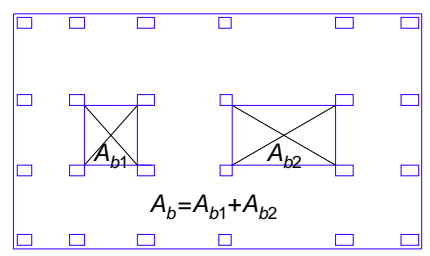

(c)
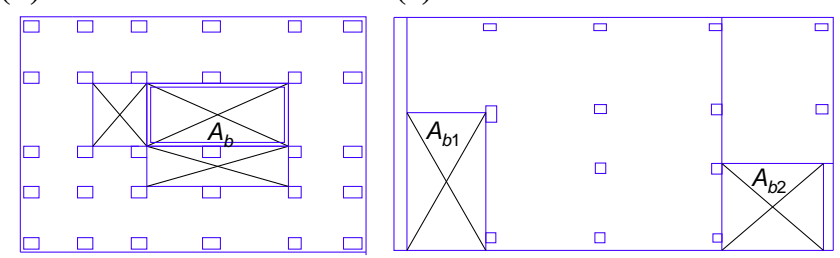

Figure 5.

Floor discontinuity conditions 
If the ratio between the total areas of openings to the gross floor area is greater than one-third, the diaphragm should be divided into simple and regular forms to provide the continuity in the distribution of the earthquake forces on slabs, and subsequently to the columns and shear walls (Ambrose and Vergun, 1985).

The reinforcement around the corners and edges of the openings may contribute to the continuity in floors (Arnold and Reitherman, 2002). The rigidity of the columns and beams around the openings should be increased or shear walls should be placed around the openings to balance the rigidity between floors (Atımtay, 2000).

The buildings having the same floor opening rate when compared with changing the location of the shear walls and openings. It is observed that the buildings having floor openings on corners or on one side show bad seismic behaviour. On the other hand, the buildings having a central floor opening and L-shaped shear walls on the corners show better earthquake performance than the other models (Figure 6). Therefore, it can be deduced that the relationship between the location of the floor openings in plan and its interaction with load bearing system have a significant importance on the earthquake performance of the building (Inan, 2010).

\subsection{Projections in plan (A3) and solution suggestions}

Projections in plan called A3 irregularity are where projections beyond the reentrant corners in both of the two principal directions in plan exceed the total plan dimensions

\section{Evaluation of structural irregularities}

309 (a)

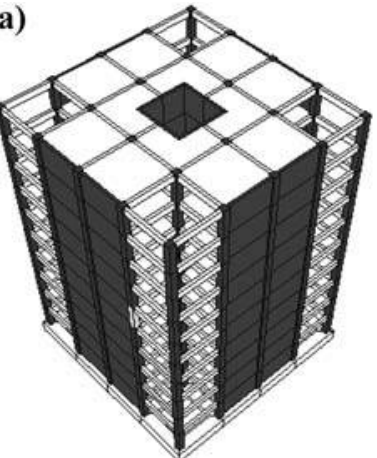

(c)

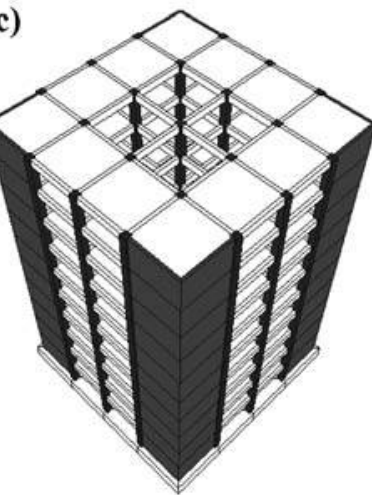

(b)



(d)

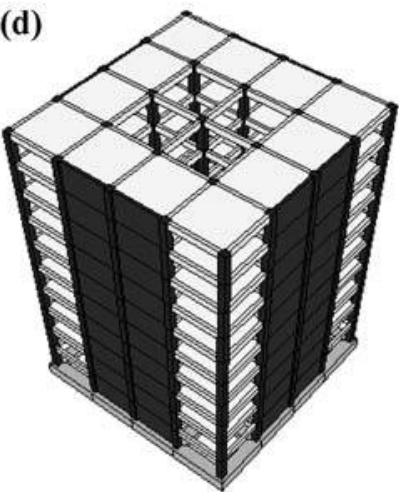

Figure 6.

Interaction between floor discontinuity and structural system 
$\mathrm{SS}$

29,4

310

Figure 7.

Projections in plan

Figure 8.

Nonparallel axis of the building in the respective directions by more than 20 per cent (TEC, 2007) (Figure 7).

The main aim of projections is to animate the building. The buildings which have large projections are seriously damaged from earthquakes (Ersoy, 1999). There are two major reasons of this condition. The first is the projections or the wings. They make different movements in different directions. This causes torsion, and natural rotation in the building. It inclines to distort the building form. That is why; torsional forces are so difficult to analyse and predict (Arnold and Reitherman, 2002). The second is the stress concentration at the notch points in the reentrant corners. Buildings can be separated blocks with seismic separation joints to prevent the irregularity.

\subsection{Nonorthogonal irregularity of the axis of structural elements (A4) and solution suggestions}

These are the cases where the principal axes of vertical structural elements in plan are not parallel to the considered orthogonal earthquake directions (Figure 8) (TEC, 2007).

This type of irregularity is commonly seen as a result of the street intersections or requirements of the space organization in design. Architects, who are the designer of the buildings, generally begin planning to abide by the parcel form. Their main goal for doing this is to take advantage of the maximum parcel area in line with owner requirements. The structures consisting of nonparallel axis will be created such as these requirements.
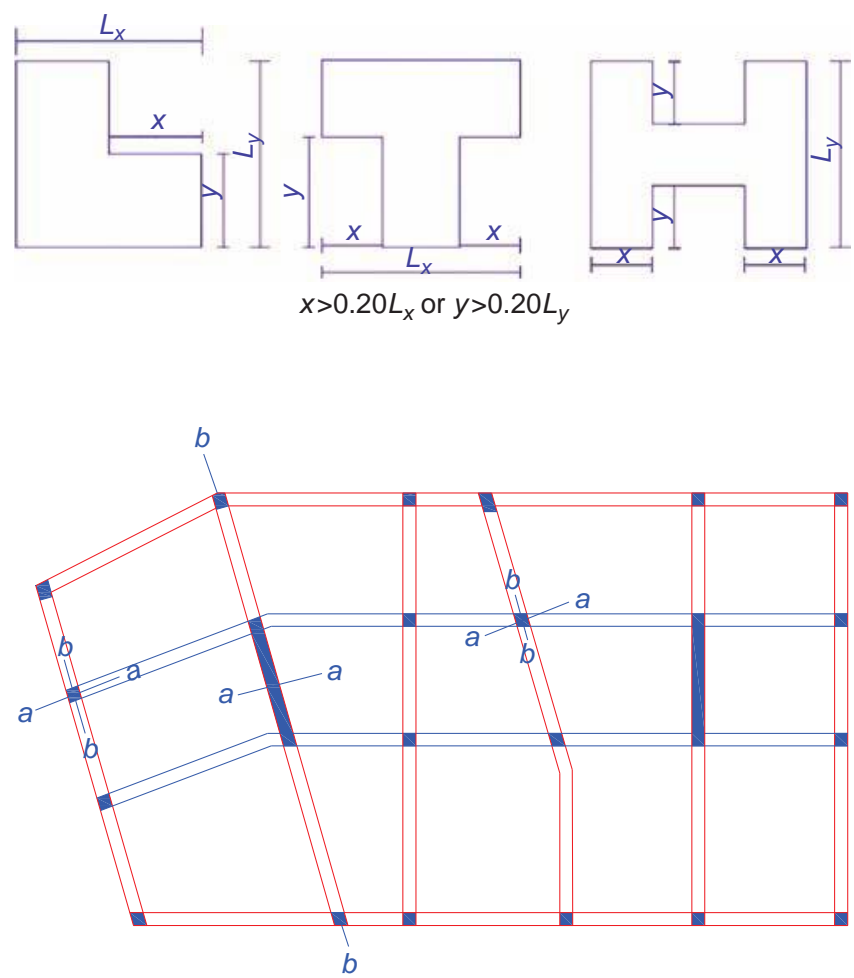
Favourable solutions should be developed in order to reduce the negative effects of torsion on this type of building. Beam connections with nonparallel axes are not safe in terms of lateral earthquake loads. They cause additional torsional moments. Nevertheless, one should avoid the creation of a short and over-rigid beam, because excessive torsional irregularity may occur in these (Özmen and Ünay, 2007).

If it is necessary to construct a building with different angles, two different solution methods can be applied described as follows:

- Separating the building to the regular and simple parts by using sesimic separation joints.

- Increasing the internal force values in nonparallel structural elements.

Internal forces in vertical structural members can be increased as if the earthquake forces come from both directions (Tezcan, 1998). Under the combined effects of independently acting $x$ and $y$ direction earthquakes to the structural system, internal forces in element principal axes $a$ and $b$ shall be obtained by Equation (2) such that the most unfavourable results are used in design (TEC, 2007).

$$
\begin{array}{lll}
B_{a}= \pm B_{a x} \pm 0.30 B_{a y} & \text { or } & B_{a}= \pm 0.30 B_{a x} \pm B_{a y} \\
B_{b}= \pm B_{b x} \pm 0.30 B_{b y} & \text { or } & B_{b}= \pm 0.30 B_{b x} \pm B_{b y}
\end{array}
$$

\section{Irregularities in vertical direction}

Irregularities in vertical direction comprise of three types of structural irregularity. These are weak storey, soft storey, discontinuity of structural elements. In this part, these irregularities are investigated in detail with their solutions.

\subsection{Weak storey irregularity (B1) and solution suggestions}

This irregularity is the case where in each of the orthogonal earthquake directions, strength irregularity factor $\left(\eta_{c i}\right)$, which is defined as the ratio of the effective shear area of any storey to the effective shear area of the storey immediately above, is less than 0.80 (Figure 9). If the ratio is between 0.8 and 0.6 , there exists weak storey irregularity

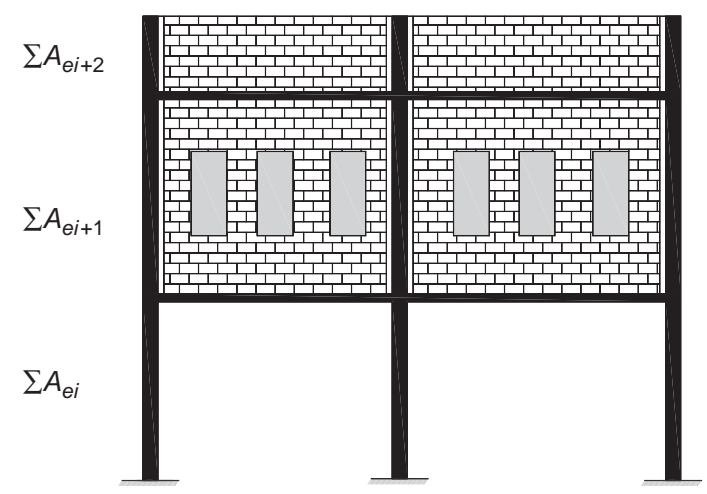

Figure 9. Formation mechanism of weak storey (B1) 
SS

29,4

312 in structure. But, if it is less than 0.6, the structure must be redesigned until appropriate range of values are gained (TEC, 2007).

$$
\begin{gathered}
\sum A_{e}=\sum A_{w}+\sum A_{g}+0.15 \sum A_{k} \\
\eta_{c i}=\left(\sum A_{e}\right)_{i} /\left(\sum A_{e}\right)_{i+1}<0.80
\end{gathered}
$$

Weak storey is a type of vertical configuration problem in which there is a major reduction in strength when it is compared with above (Arnold and Reitherman, 2002). It generally occurs at the first storey due to the greatest loads accumulating at this storey. It results from the lesser strength or major flexibility between stories. If all stories of the building are nearly equal in terms of strength or stiffness, earthquake forces can be distributed homogeneous among stories. However, architectural requirements in usage of a building restrict that type of planning. For instance, while the upper stories are used for housing, the ground floors are used as shops almost all residential buildings in Turkey. Shops are designed as to have large window openings due to the function of the space. Therefore, the ground floors have less strength than the upper floors.

Vertical setbacks and overhangs cause weak storey irregularity. Bayülke (2001) indicates maximum projection dimensions in vertical (Figure 10).

There are various alternative solutions to reduce or eliminate the negative effects of the weak storey irregularity on buildings (Figure 11). They can be listed as follows:

- to create partly setbacks as pyramidal configuration;

- to create seismic separation joints;

- to provide equal strength between stories (Figure 11a-11c);

- to leave joint between column and wall (Figure 11a); and

- to make isolation.

\subsection{Soft storey irregularity (B2) and solution suggestions}

This irregularity is the case where in each of the two orthogonal earthquake directions, stiffness irregularity factor $\left(\eta_{k i}\right)$, which is defined as the ratio of the average storey drift at any storey to the average storey drift at the storey immediately above or below, is $>2.0$ (TEC, 2007).
Figure 10.

Maximum projections in vertical direction
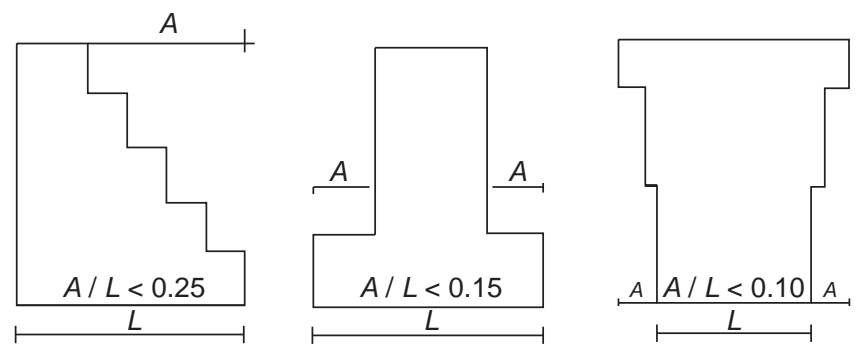
(a)

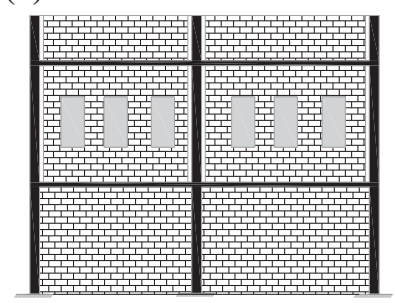

(c)

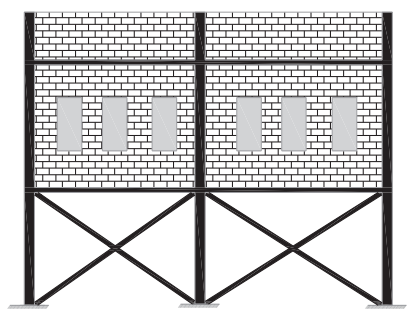

(b)

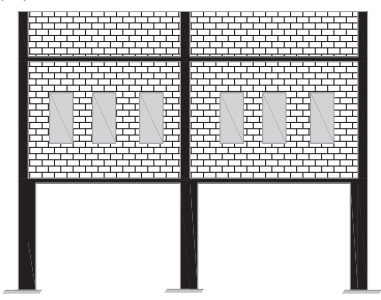

(d)

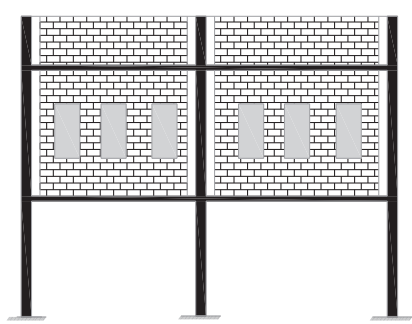

Evaluation of structural irregularities

313

Figure 11.

Notes: (a) add walls; (b) increase cross-sections of columns;

(c) add steel bars; (d) isolation gaps

$$
\begin{aligned}
{\left[\eta_{k i}\right.} & =(\Delta i / h i) \operatorname{ort} /(\Delta i+1 / h i+1) \text { ort }>2.0 \text { or } \\
\eta_{k i} & =(\Delta i / h i) \operatorname{ort} /(\Delta i-1 / h i-1) \text { ort }>2.0]
\end{aligned}
$$

There are various parameters that cause soft storey irregularity. The height difference between the floors is a remarkable one among them (Figure 12). The ground floor of a building is generally designed as higher than the upper floors due to the user requirements. Therefore, it causes a difference in rigidity or stiffness between floors. Ground floors show more displacement than the others. The other significant one is open ground storeys (i.e. shops, meeting rooms, banking halls, etc.). In these buildings, while great storey drift occurs in the ground floor, the upper floors move like a diaphragm (Figure 12). High stress concentration occurs along the connection line between the ground and first floor that leads to distortion or collapse in structures (Tezcan, 1998; Bayülke, 2001).



Figure 12. Storey displacements and hinges 
SS

29,4

314

To prevent this irregularity, the solution suggestions can be listed as follows:

- add bracing elements which stiffen the columns up to a level;

- add additional columns at ground storey to increase the stiffness;

- increase the cross-sections of the columns at first storey;

- add external buttresses (Figure 13b); and

- create vaults on the ground floor (Figure 13a).

4.3 Discontinuity of vertical structural elements (B3) and solution suggestions

This irregularity is described as the case where vertical structural elements are positioned unsuitably. This irregularity is clarified as follows (TEC, 2007):

- gusseted columns or the columns which rests on cantilever beams are prohibited;

- in the case where a column rests on a beam supported with columns at both ends, all internal forces consisting vertical loads and seismic loads from the earthquake direction shall be increased by 50 per cent at all sections of the all beams and the columns which are adjacent to the beam;

- in no case the shear walls should be allowed to rest under the columns; and

- in no case the shear walls should be allowed to rest on the beams.

\subsection{Short column effect (C1) and solution suggestions}

When a building has both long and short columns in the same storey, the columns exposed to different shear forces due to their height differences. The lateral loads first come to the long and flexible columns, and then go towards the short column and accumulate in there. Due to the excessive accumulation of the seismic energy, shear cracks (X-shaped) occur at both ends of the columns (Murthy, 2007).

The conditions causing short columns are mezzanine floors, mechanical floors, hillside sides, graded foundations, adjacent columns to the openings of stair landings (Figure 14).

Horizontal bracing throughout the height and into the column above can be accepted as an alternative solution for preventing or reducing the short column effect.

(a)

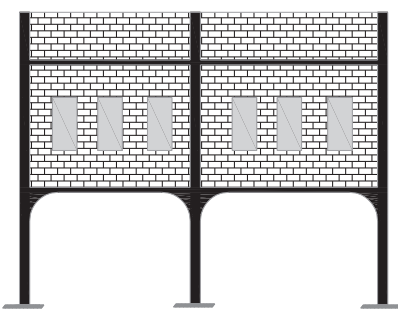

(b)

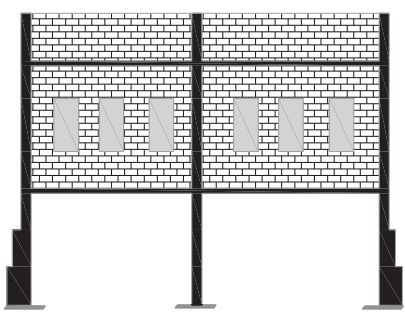

Figure 13.

Solutions for soft storey
Notes: (a) vaults; (b) external buttresses 
(a)

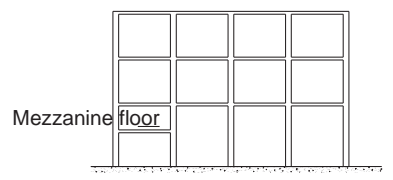

(b)

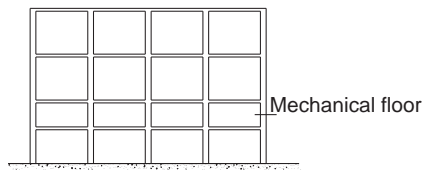

(d)

(c)

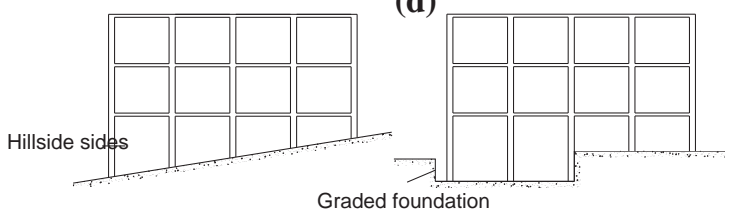

(e)

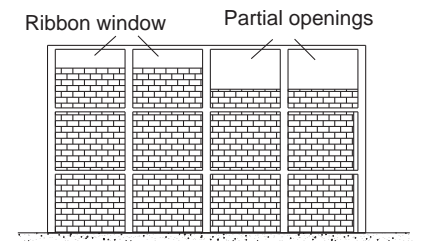

(f)

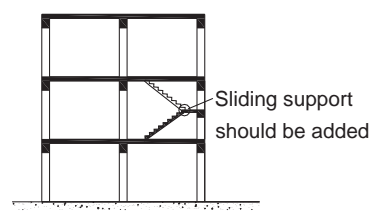

Evaluation of structural irregularities

315
Figure 14.

Formations of short columns

This solution provides regular distribution in stiffness among the columns. It can be used in mechanical floors, adjacent openings to the columns and in stair landings. Heavy nonstructural walls play a major role on short columns. Therefore, heavy nonstructural walls must be isolated from the columns to prevent the formation of the short column (Naeim, 2001).

The foundation of a structure should be located on the same plane surface. This is taken into consideration on hillside sides and one should avoid designing graded foundations (Figure 14d). To prevent short column due to the stair landing, sliding support should be placed between the steps on the intermediate landing (Figure 14d).

\subsection{Weak column-strong beam (C2) and solution suggestions}

In a structure, it is desired that beams should begin deforming before columns. Failure in a column can affect the stability of the overall building. However, beam deformation partly affects the building (Bayülke, 2001). Therefore, beams need to be made ductile rather than the columns.

Plastic hinging at both ends of the columns may initiate a storey displacement or even leading to the overall collapse of the building (Bayülke, 2001). The beams should have weakest links instead of columns to prevent plastic hinging in columns. This condition can be provided by correctly sizing the structural members and using sufficient amount of steel in them (Murthy, 2007).

\subsection{Pounding effects (C3) and solution suggestions}

Pounding is a damage type in two buildings or different parts of the same building under earthquake loads. It commonly occurs due to the insufficient seismic gap or no gap between two adjacent buildings (Doğan, 2007).

There are various parameters causing this irregularity. These can be listed as soft ground floors, irregular plan geometry, setbacks and liquefaction. 
SS

29,4

316
The soft ground floors lead to extreme displacement or even collapse in structures. Adjacent buildings with irregular plan geometry expose to torsional effects under earthquake loads and pounding is observed due to the less seismic joint gaps. Moreover, the setbacks cause stress concentration and the blocks hit each other due to the different vibrations of blocks. The soil type where the structure is constructed affects the seismic behaviour of the structure. Liquefaction can occur in poor quality soil, and the structures usually overturn to one side without big damages in upper floors.

While dynamic behaviour of buildings is investigated, it is accepted that the mass of the building is accumulated on floor level. Thus, a mass accumulation is defined for each storey of the building ensuring each storey has rigidity and damping coefficient (TEC, 2007). The degree of the pounding shows differences for the pounding conditions in different floor levels (Figure 15). If the floors are not in the same level between two adjacent buildings, hammering occurs and damage potential increases.

The minimum size of the seismic gaps should be $30 \mathrm{~mm}$ up to $6 \mathrm{~m}$ height. From thereon a minimum $10 \mathrm{~mm}$ shall be added for every $3 \mathrm{~m}$ height increment (TEC, 2007).

The sizes of gaps to be left in the seismic joints between building blocks or between the old and newly constructed buildings should be determined with respect to the following conditions. Size of gaps should not be less than the square root of the sum of squares of average storey displacements multiplied by the coefficient $\alpha$ specified below (TEC, 2007):

- $\alpha=R / 4$ should be taken if all floor levels of adjacent buildings or building blocks are the same.

- $\alpha=R / 2$ should be taken if any of the floor levels of adjacent buildings or building blocks are not the same.

(a)
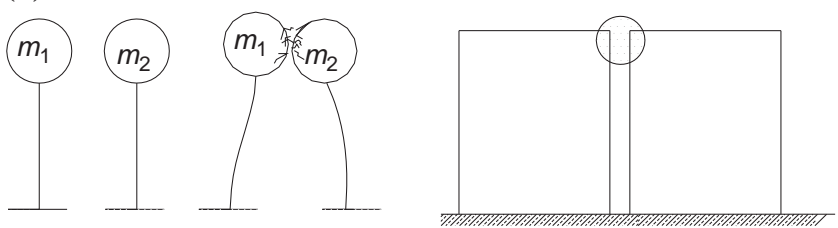

(b)
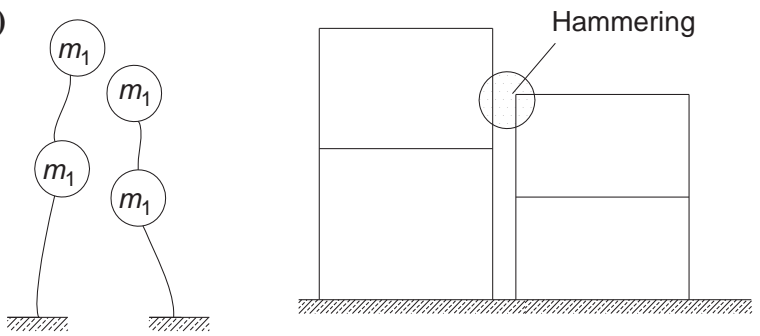

Figure 15.

Dynamic pounding effects
Notes: (a) same storey level; (b) different storey level 


\section{Conclusions}

In this study, the structural irregularities are investigated comprehensively with solutions suggested in literature and TEC, and then the effective factors on earthquake performance of structures are explored. These factors are:

- architectural form;

- rigidity distribution;

- location of shear walls in plan;

- the floor opening rates and its location in plan;

- projection rates and symmetry in plan;

- overhangs;

- the relationship of rigidity and strength between floors;

- short columns;

- weak column-strong beam; and

- pounding effect.

The structural irregularities are described in the TEC. However, in practise it is quite significant and required to gain an understanding of the problems in projects at least in terms of structural irregularity, and then manage to solve the problems using problemoriented solutions. Earthquake is a common and significant research field ranging from social sciences to technical sciences. However, the structural problems caused by an earthquake are generally seen as an engineering problem even though they can be eliminated through the design phase. Safety precautions should have a significant position in architectural design.

If the factors causing structural irregularities are investigated, it is observed that many of them can be prevented with the decisions in the early stage of architectural design. Architects are primary responsible from the overall picture observed after earthquakes due to the being the designer of the buildings. It is important to underline that ERD should not be seen just as an engineering calculation issue. Nevertheless, there is still hope for earthquake resistant structures through an understanding of the problems and problem-oriented solutions.

\subsection{Future plans}

Further studies in this subject may address the validity of the mentioned solution suggestions by actively engaging in the process of architectural and structural design. In other words, more effective theoretical principles for different structural irregularity conditions can be demonstrated by means of a structural analysis software. Thus, a systematically categorized design guide can be created and new typologies of earthquake resistant buildings can be developed. On the other hand, the material and structural properties of $R / C$ can be explored in detail to find innovative ways for preventing irregularity conditions in structures.

\section{References}

Aka, I.., Keskinel, F., Çı1l, F. and Çelik, C. (2001), Betonarme [Reinforced Concrete], Birsen Press, Istanbul.

Ambrose, J. and Vergun, D. (1985), Seismic Design of Buildings, John Wiley \& Sons, New York, NY.
Evaluation of structural irregularities 
SS

29,4

318
Arbabian, H. (2000), "The role of architects in seismic design", International Conference on the Seismic Performance of Traditional Buildings in İstanbul, Turkey, Republic of Turkey Ministry of Culture, ICOMOS International Wood Committee, İstanbul, Turkey, pp. 83-91.

Arnold, C. and Reitherman, R. (2002), Building Configuration and Seismic Design, John Wiley \& Sons, New York, NY.

Atımtay, E. (2000), Açıklamalar ve Örneklerle Afet Bölgelerinde Yapılacak Yapılar Hakkında Yönetmelik [Explanations and examples Regulations on Buildings Constructed in Disaster Areas], Bizimburo Press, Ankara.

Bachman, H. (2003), Seismic Conceptual Design of Buildings - Basic Principles for Engineers, Architects, Building Owners, and Authorities, Swiss Federal Office for Water and Geology, Bern.

Bayülke, N. (2001), Depreme Dayankh Betonarme ve Yığma Yapı Tasarm [Earthquake Resistant Reinforced Concrete and Masonry Building Design], Civil Engineering Press, Izmir.

Çağatay, I.H. (2005), "Experimental evaluation of buildings damaged in recent earthquakes in Turkey", Engineering Failure Analvsis, Vol. 12 No. 3, pp. 440-52.

Celep, Z. and Kumbasar, N. (2004), Deprem Mühendisligine Giriş ve Depreme Dayamkl Yapı Tasarm [Introduction to Earthquake Engineering and Earthquake Resistant Building Design], Beta Press, İstanbul.

Charleson, A. (2008), Seismic Design for Architects: Outwitting the Quake, Elsevier, Burlington, WI.

Dimova, S.L. and Alashki, I. (2003), "Seismic design of symmetric structures for accidental torsion", Bulletin of Earthquake Engineering, Vol. 1 No. 2, pp. 303-20.

Doğan, M. (2007), Yapularn Deprem Analizi [Earthquake Analysis of Buildings], Osmangazi University Press, Eskisehir.

Döndüren, S.M., Karaduman, A., Coğurcu, T.M. and Altin, M. (2007), "Yapılarda burulma düzensizliği”, [Torsional irregularity in buildings], Selcuk University Technic Science Journal, Vol. 6 No. 1, pp. 42-52.

Dowrick, D.J. (1987), Earthquake Resistant Design for Engineers and Architects, John Wiley \& Sons, Chichester.

Erman, E. (2002), Deprem bilgisi ve deprem güvenli mimari tasarm [Earthquake Information and Earthquake Safety Architectural Design], ODTU Press, Ankara.

Ersoy, U. (1999), "Binalarm Mimarisinin ve Taşıyıcı Sisteminin Deprem Dayanmmna Etkisi”, [The Earthquake Effect of architectural and structural system of buildings], in Aktüre, T., Deprem güvenli konut sempozyumu, ODTÜ, Ankara, pp. 65-77.

Gönençen, K. (2000), Mimari Tasarmmda Depreme Karşı Yapı Davranışımn Düzenlenmesi [Organization of Eartquake Behaviour of Structure in Architectural Design], Teknik yayınevi, Ankara.

Gülay, F.G. and Çalım, G. (2003), "A comparative study of torsionally unbalanced multi-storey structures under seismic loading”, Turkish Journal Engineering Environment Science, Vol. 27 No. 1, pp. 11-9.

İnan, T. (2010), "The interaction of reinforced concrete skeleton systems and architectural form subjected to earthquake effects", Master thesis, IYTE, İzmir.

Karaesmen, E. (2002), Öncesiyle Sonrasiyla Deprem [Before and After Earthquake], At1lım Üniversitesi yayınları, İstanbul.

Mertol, A. and Mertol, H.C. (2002), Deprem Mühendisligì, Depreme Dayankh Yapı Tasarm [Earthquake Engineering, Earthquake Resistant Design], Kozan Press, Ankara. 
Murthy, D.B.N. (2007), Disaster Management: Text and Case Studies, Deep Publications, New Delhi, IN.

Naeim, F. (2001), The Seismic Design Handbook, Van Nostrand Reinhold, New York, NY.

Özmen, C. and Ünay, A.I. (2007), "Commonly encountered seismic design faults due to the architectural design of residential buildings in Turkey", Building and Environment, Vol. 42 No. 3, pp. 1406-16.

Özmen, G. (2004), “Çok Katlı Yapılarda Aşırı Burulma Düzensizliği” [Excessive torrisional irregularity in multi-storey buildings], IMO Teknik Dergi, Vol. 210 No. 1, pp. 3131-44.

Evaluation of structural irregularities

Tezcan, S. (1998), Depreme Dayanık Tasarm için Bir Mimarm Seyir Defteri [An Architect's Log Book for Earthquake Resistant Design], Türk Deprem Vakfi, İstanbul.

Tuna, M.E. (2000), Depreme Dayankh Yapı Tasarm [Earthquake Resistant Building Design], Tuna Eğitim ve Kültür Vakf, Ankara.

Turkish Earthquake Code (TEC) (2007).

Zacek, M. (2002), Depreme Dayanıkh Yapı Tasarımı Ön Proje Aşaması [Earthquake Resistant Building Design, Initial Design Stage], Yıldız Technic University, İstanbul.

\section{Corresponding author}

Tugba Inan can be contacted at: tugbaInan85@gmail.com

To purchase reprints of this article please e-mail: reprints@emeraldinsight.com Or visit our web site for further details: www.emeraldinsight.com/reprints 
This article has been cited by:

1. Tugba Inan, Koray Korkmaz, Ismail H. Cagatay. 2014. The effect of architectural form on the earthquake behavior of symmetric RC frame systems. Computers and Concrete 13:2, 271-290. [CrossRef] 